\title{
Corporate Finance Practices in Canada: Where Do We Stand?
}

\author{
H. Kent Baker* \\ American University, USA \\ Shantanu Dutta \\ University of Ontario Institute of Technology, Canada \\ Samir Saadi \\ Queen's University, Canada
}

This study investigates the financial practices of Canadian firms involving capital budgeting, cost of capital estimation, capital structure, and real options. Survey respondents express a strong preference for net present value followed by internal rate of return and payback methods. The least popular capital budgeting technique is real options. Unlike their U.S. and European counterparts, Canadian firms rely more on subjective risk assessments in adjusting their discount rate. The use of subjective judgment by Canadian managers also applies to risk analysis, forecasting project cash flows, and estimating the cost of equity capital. This finding differs markedly from the widespread use of the capital asset pricing model by U.S. and European firms. In examining capital structure choice, the results show support for trade-off theory relative to pecking order theory. Finally, firm size and the education of the chief executive officer influence corporate finance decisions. (JEL: G35)

Keywords: Capital budgeting, cost of capital, risk analysis, real options.

\section{Introduction}

This study presents survey results from a large sample of Canadian firms designed to investigate practices involving capital budgeting, cost of equity estimation, capital structure preferences, and real options. For

\footnotetext{
* Corresponding author. The authors thank the anonymous reviewer as well as Alfred Davis and Fodil Adjaoud for helpful comments and suggestions.

(Multinational Finance Journal, 2011, vol. 15, no. 3/4, pp. 157-192)

(C) Multinational Finance Society, a nonprofit corporation. All rights reserved. DOI: $10.17578 / 15-3 / 4-1$
} 
decades these topics have received much attention from both the academic and professional community with Istvan (1961) providing one of the earliest empirical studies. More recent studies conclude that corporate finance practices have become more aligned with finance theory over time. For instance, Gitman and Vandenberg (2000), who examine cost of capital estimation techniques in large U.S. firms using the same survey instrument as in their earlier 1980 study (Gitman and Mercurio, 1982), find an increase in the popularity of the capital asset pricing model (CAPM).

Most studies of corporate finance practices focus on large U.S. firms. Few researchers except Jog and Srivastava (1995) examine the Canadian market. However, they only investigate large firms and use a survey covering few capital budgeting, risk assessment, and cost of capital techniques. For instance, these authors investigate only four capital budgeting techniques: accounting rate of return (ARR), payback period (PBP), internal rate of return (IRR), and net present value (NPV). By contrast, the current survey covers nine capital budgeting techniques including real options, and uses a sample nearly twice that of Jog and Srivastava. Moreover, while the current study surveys all Canadian public firms, Jog and Srivastava examine only large firms. This limitation reduces the scope of their study and prevents possible generalization of their findings to the entire Canadian context. In contrast, the non-response bias analysis, which is discussed in Section III, suggests that the sample is representative of the population of Canadian public firms with respect to size but also to several other dimensions. Further, unlike Jog and Srivastava (1995), survey responses from the current study are examined conditional on firm size and CEO education as in Graham and Harvey (2001). Finally, given that Jog and Srivastava conducted their survey in 1991 and the growing interest in corporate finance practices in the academic literature, a need exists for a current and more comprehensive study on Canadian finance practices.

Athanassakos (2007) uses a sample of large Canadian public firms to examine the use of value-based management (VMB) methods and how they influence a firm's stock performance. He also identifies characteristics of both firms and management that increase the likelihood of employing VMB methods. Although this study is not directly comparable to the stream of capital budgeting studies that use a survey approach, it provides good insights on how corporate finance practices influence shareholders' wealth.

Graham and Harvey (2001) survey U.S. and Canadian executives who are members of the Financial Executive Institute (FEI) but they do 
not specify the percentage of Canadian managers responding to their survey. The results show that their findings reflect mainly the United States view and are similar to previous U.S. surveys. For example, Graham and Harvey report that most chief executive officers (CEOs) use CAPM to compute the cost of equity. Yet, the results show that the majority of responding Canadian firms use subjective judgment with a substantially lower percentage using CAPM. One possibility for this difference is that the low proportion of Canadian executives included in the Graham and Harvey study dilutes the Canadian view.

Other studies (Chew, 1997; La Porta et al., 1998; Rajan and Zingales, 2003; Lasfer and Alzahrani, 2009; Aggarwal et al., 2009) stress the importance of country-level variables in shaping a firm's corporate decisions. For example, Brounen, De Jong, and Koedijk (2004) find that capital budgeting practices in Europe tend to vary by country of origin. As Baker et al. (2009) observe, several major differences exist between the United States and Canadian contexts that could affect corporate finance practices. For example, Canadian firms are smaller in size, have more concentrated ownership structure and weaker corporate governance than their U.S. counterparts (Morck, Stangeland, and Yeung, 2001; King and Segal, 2003; Bris, 2005; Leung, Meh, and Terajima, 2008). Section V provides a discussion of how these differences help explain the discrepancies between U.S. and the Canadian survey results. Thus, combining the views of U.S. and Canadian executives could distort the results reported by Graham and Harvey (2001).

Capital budgeting surveys typically share the same main goal of assessing whether firm practices conform to finance theory. With the notable exception of Graham and Harvey (2001) and Brounen, De Jong, and Koedijk (2004), these studies focus mainly on the popularity of traditional capital budgeting techniques. Although finance theory favors discounted cash flow (DCF) techniques to less conceptually correct methods, DCF techniques have limitations. For instance, DCF methods often fail to provide sound valuation when the business environment is uncertain and ignore the value created by flexibility in management decisions (Brealey, Myers, and Allen, 2007). Using a real options approach can help to overcome these limitations and to provide more accurate valuation than the static DCF approaches (Brennan and Schwartz, 1985; Paddock, Siegel, and Smith, 1988; Pindyck, 1991; Ingersoll and Ross, 1992; Trigeorgis, 1993).

In practice, top managers do not appear to share the increasing interest in real options from academicians and financial professionals 
with similar enthusiasm. As Chance and Peterson (2002, p. 95) note, "Empirical research has provided some, but very limited, support for the real-world applicability of real options models." According to the Canadian survey results, the real options approach is the least popular of the nine capital budgeting techniques presented in the survey with only $17 \%$ of participants indicating using them. Graham and Harvey (2001) and Block (2007) document this relatively weak support for real options in the United States, while Brounen, De Jong, and Koedijk (2004) find similar results in Europe. These surveys, however, provide little rationale for the low popularity of real options because they simply report the percentage of responding firms using real options. While Triantis and Borison (2001) ask firms why they use real options, they examine only 35 companies that are already using or considering real options. Hence, survey evidence on why firms do not use real options is largely absent from the literature. This study attempts to uncover some reasons or obstacles inhibiting firms from using real options. Specifically, the study provides evidence about the importance that respondents attach to eight reasons for not using real options such as a lack of expertise or knowledge and the complexity of applying real options in practice. Identifying these reasons may help both academicians and financial professionals become aware of factors limiting the use of real options.

This study contributes to the literature on corporate finance practices in several ways. First, although many surveys examine corporate finance practices, few report evidence from Canadian firms. This study provides the most comprehensive examination of Canadian firms regarding capital budgeting techniques, cost of capital estimation, and capital structure to date and permits determining whether such practices have evolved over time. Baker, Singleton, and Veit (2011) provide for a synthesis of the survey-based literature on corporate finance practices. Second, this approach permits examining the extent to which corporate finance practices documented from numerous U.S. studies hold in Canada. Third, this investigation of real options provides new insights about why managers use and do not use real options when making capital budgeting decisions. Fourth, the study provides a basis for examining the level of support for two competing capital structure theories - the static trade-off theory and pecking order theory. Finally, the study examines how firm characteristics and CEO education may affect finance practices in Canada. Graham and Harvey (2001), for instance, find that firm size and whether the CEO holds an MBA degree shape corporate finance practices of U.S. firms. Given the differences 
between the United States and Canada, determining whether these two dimensions affect Canadian finance practices is important.

Survey-based research offers several benefits. The main point of conducting a survey is to get information that is otherwise unavailable. Thus, the survey approach can provide unique information that complements the results obtained from traditional large-sample analysis. As Graham and Harvey (2001) note, large-sample studies often have weaknesses related to variable specification and the inability to ask qualitative questions. Surveys also offer considerable versatility and flexibility in asking a wide variety of questions. Additionally, surveys provide a direct way for outsiders to understand how companies operate. Thus, they permit identifying where theoretical concepts fall short in addressing practical issues in corporate decision making, which in turn helps identify future research opportunities. Finally, using a survey enables researchers to choose the volume of data to collect and the degree of complexity depending on the scope of information requirements and resource availability.

As Chu and Partington (2001, p. 166) note, "the availability of large computerized databases has been a boon to researchers by freeing them from much of the tedium of data collection and management." Yet, such availability of data has caused researchers to become distanced from their data and accept it without question. The risk of uncritical acceptance of data may lead the researcher to erroneous conclusions. Chu and Partington further note that this problem is compounded in multi-country studies because a single researcher is unlikely to have the knowledge across all countries of conditions and institutional detail that helps identify anomalous data and results.

Several important results emerge from this survey-based study. In line with finance theory, the evidence shows a strong preference for NPV followed by IRR and PBP. By contrast, Jog and Srivastava (1995) report in their 1991 survey that IRR and PBP dominate the NPV method. The results also differ from studies showing that IRR in the United States and PBP in Europe are the most popular capital budgeting techniques. Among the capital budgeting techniques, the survey results show that using real options is even less popular in Canada than in the United States and Europe. Canadian managers indicate that the main reason for not using real options is the lack of expertise or knowledge. Clearly this finding is contrary to the optimistic predictions from the academic and professional community about the prospective widespread use of real options as a powerful capital budgeting and management tool. 
Regarding risk analysis, the study documents that Canadian managers rely mainly on subjective judgment, which is inconsistent with theory. Subjectivity also applies when adjusting the discount rate for risk, forecasting project cash flows and estimating the cost of equity capital. These findings diverge markedly from the approaches used by U.S. and European financial managers when dealing with risk in capital budgeting.

In examining capital structure choice, the results of the survey provide support for trade-off theory relative to pecking order theory. Further, Canadian managers exhibit tighter target capital structure than their U.S. and European counterparts. Finally, the results indicate that firm size and CEO education influence corporate finance decisions.

The remainder of the paper proceeds as follows. Section II discusses the research methodology and describes the survey sample. Section III discusses potential limitations of the survey approach while Section IV presents and discusses the main findings. Section V provides an explanation of the differences between U.S. and Canadian survey results regarding corporate finance practices. Finally, Section VI provides a summary and conclusions.

\section{Research Methodology and Sample Selection}

\section{A. Survey Design}

A mail survey serves as the major means of gathering data. The survey is available from the authors upon request. Previous survey studies especially Graham and Harvey (2001) provide the inspiration for the current study. The current survey contains two groups of questions. The first group focuses on capital budgeting methods, cost of capital, and capital rationing and the second group consists of questions on real options. The questionnaire concludes by inquiring about the backgrounds of respondents including their involvement in their firm's capital budgeting process and current position. Survey recipients are also asked whether the company's CEO holds an MBA degree.

For most questions in the first group, survey recipients are asked to indicate how frequently they use each of the capital budgeting and cost of capital techniques provided in the survey using a five-point Likert scale where $0=$ never, $1=$ rarely, $2=$ sometimes, $3=$ often, and $4=$ always. A t-test is used for the null hypothesis that the mean response for each method equals 0 (never). 
The section on real options contains six questions: The first two questions ask respondents to indicate the reason(s) underlying their use of real options. The first question asks whether their company uses real options in making capital budgeting decisions. The second question provides six reasons and asks respondents to indicate the level of importance of each reason on a four-point scale where $1=$ none, $2=$ low, $3=$ moderate, and $4=$ high. The third question is an open-ended question asking respondents to state the most important reason for their firm using real options.

The section on real options ends with two questions on why their company does not use real options. In one question, eight reasons are provided and respondents are asked to choose one or more based on the four-point importance scale where 1 = none, 2 = low, 3 = moderate, and 4 = high. The last question is an open-ended question asking respondents to specify the most important reason for not using real options.

\section{B. Sample Description}

The initial survey sample consisted of all 847 Canadian firms listed on Toronto Stock Exchange (TSX) at the beginning of 2006. To be included in the final survey sample, each firm had to have the following data available from the Stock-Guide database: (1) revenues, (2) debt-to-equity ratio, and (3) price-to-book ratio. Instead of using Worldscope and Compustat, Stock-Guide is used because this specialized database provides more comprehensive coverage of Canadian public firms and leads to a larger sample size. Such data is used to test for differences between responding and non-responding firms. Deleting firms with missing data resulted in a final sample of 762 firms.

On February 5, 2006, a personalized cover letter requesting participation in this study along with a stamped self-addressed return envelope and the two-page survey instrument was mailed to the chief financial officer (CFO) of each of the 762 firms. The names and addresses of the CFOs were obtained from each company's website. The cover letter stated that if recipients are not actively involved in determining their firm's capital budgeting decision, they should give the survey to someone in their company who is involved. The survey contained a code number to avoid potentially including duplicate responses in the analysis.

The cover letter informed potential respondents that the results 


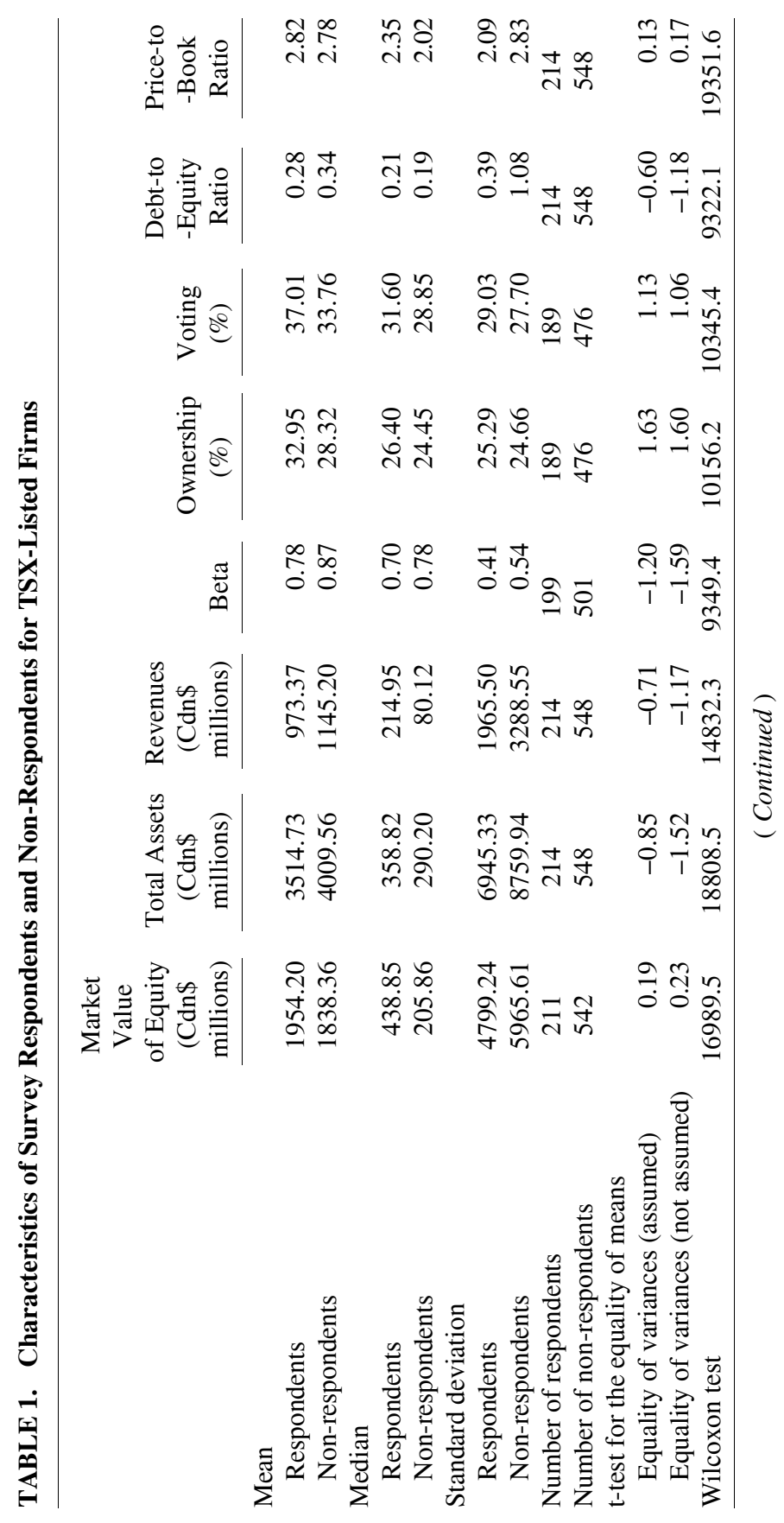




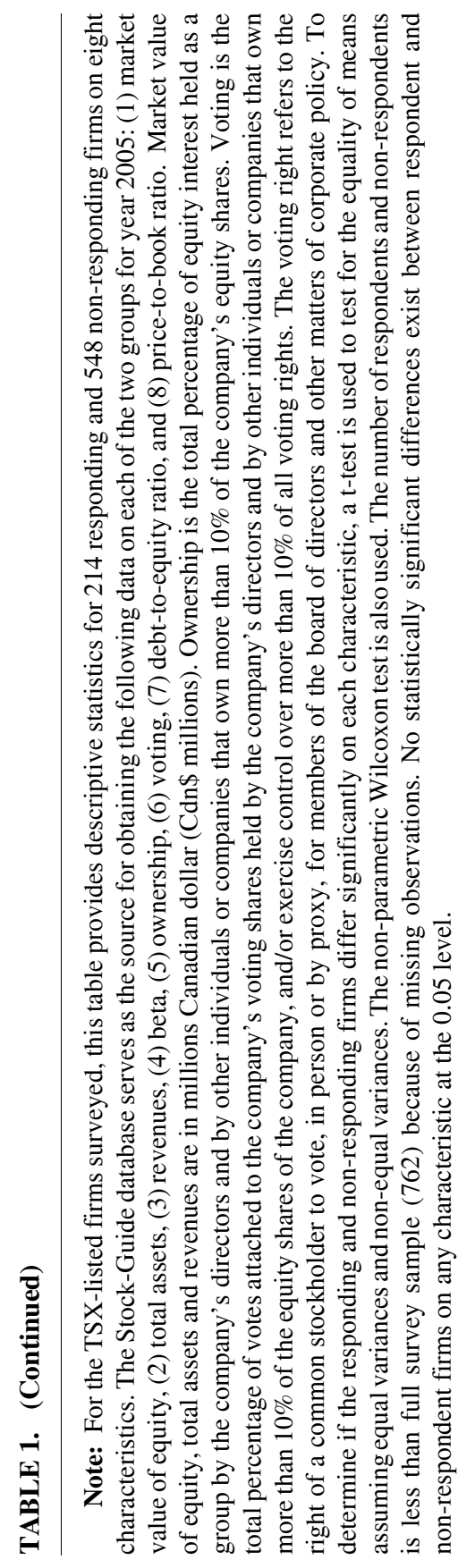


would be in summary form and would not be disclose any information about individual companies. Although including a code number may have reduced the response rate and/or introduced a response bias, having the ability to identify duplicate responses outweighs this potential limitation. A second copy of the survey was mailed to non-respondents on March 31, 2006 to increase the response rate and thereby to reduce potential non-response bias. As an inducement to increase the response rate, an executive summary of the results was offered to all interested parties.

By the end of April 2006, 214 usable responses (a 28.1\% response rate), consisting of 159 responses from the first mailing and 55 responses from the second mailing, were received. A usable response was defined as one in which a participant answered at least $90 \%$ of the questions. The response rate is considerably higher than similar survey-based studies including Trahan and Gitman (1995), Jog and Srivastava (1995), Graham and Harvey (2001), and Brounen, De Jong, and Koedijk (2004) with 12\%, 23\%, 9\%, and 5\% response rates, respectively.

Of the respondents, $89.5 \%$ report being actively involved in their firm's capital budgeting process. The most common positions or titles of the respondents are CFO (87.3\%), vice president of finance $(3.9 \%)$, and corporate controller (3.6\%). The remaining respondents belong to one of the following categories, where no category amounts to more than $3 \%$ of the responses: CEO, corporate secretary, and president. In summary, the sample represents high ranking and knowledgeable corporate executives. Of the participants, $20.6 \%$ indicate that their company's CEO holds an MBA degree.

The responses to the survey come from managers of firms in the following business sectors: manufacturing (44\%), retail and wholesale sales $(24 \%)$, and mining (14\%). The remaining business sectors (financial, high-tech, and utility) each represent less than $10 \%$ of the responses. Thus, the sample includes a wide range of industries.

Table 1 provides descriptive statistics for respondent and non-respondent firms. The data suggest that the firm characteristics of the two groups are similar. The difference in means test, which is discussed in the next section, supports this assertion. The mean firm size of respondent (non-respondent) firms, measured in terms of market value of equity is about $1,954(1,838)$ million Canadian dollars. Firm beta is about 0.78 and 0.87 for the respondent and non-respondent firms, respectively. Both groups exhibit a high level of ownership concentrations with an average around $30 \%$. A similar observation 
applies to the leverage (debt-to-equity) ratio. Finally, both respondent and non-respondent firms have an average price-to-book ratio of about 2.8 .

\section{Potential Limitations of the Survey Approach}

As with any survey, this study has several potential limitations. First, non-response bias could affect the results despite taking several steps to reduce this bias such as using multiple mailings, assuring respondents of confidentiality, and making the survey reasonably short and easy to complete. The high response rate relative to other recent surveys lessens this concern. Nevertheless, the study examines non-response bias by testing whether the means of eight firm characteristics of the 214 responding firms differ significantly from those of the 548 non-responding firms. The firm characteristics are: (1) market value of equity, (2) total assets, (3) revenues, (4) beta, (5) ownership, (6) voting, (7) debt-to-equity ratio, and (8) price-to-book ratio. A t-test is used to determine whether a significant difference exists between the means of the respondents and non-respondents on each firm characteristic. Because the standard t-test assumes equality of variances, which may not be the case, a t-test that does not assume equality of variances is also used. Because t-tests assume a normal distribution, which also may not be the case, a further test for non-response bias using a non-parametric test, specifically the Wilcoxon test, is used. The results for equality of means, reported in table 1 , show that no significant difference exists between firms of respondents and non-respondents on any of the eight characteristics at conventional levels.

As suggested by Wallace and Mellor (1988), the responses from the 159 firms that returned the survey after the first mailing are compared to those responses from the 55 firms after the second mailing. To perform the chi-square tests and to reduce the potential problem associated with small cell size, the five-point scale is collapsed to three categories - (1) never and rarely, (2) sometimes, and (3) often and always - and the four-point importance scale to two categories - (1) none and low and (2) moderate and high. The chi-square tests (not reported here but available from the authors upon request) show no significant differences between the responses to the first and second mailing at normal levels.

Besides non-response bias, the survey questionnaire may be the 
source of other potential limitations. Did respondents answer each question truthfully? Did respondents properly understand the questions? Do the responses to each question depend on the question's location in the survey? There is no evidence that respondents answered untruthfully or misunderstood the questions. Because all statements appear in one section on a single page, any potential bias based on question location appears small. The literature contains many instances of order having no effect on response rates such as Graham and Harvey (2001).

\section{Results and Discussion}

\section{A. Capital Budgeting Techniques}

The study begins by examining whether Canadian public firms use DCF methods to evaluate investment opportunities. Consistent with theory, the vast majority (84\%) of the respondents indicate that they use DCF techniques. Results presented in figure 1 also show that $58 \%$ use DCF techniques as a primary tool while about $26 \%$ use them as a secondary tool. Not surprisingly, DCF methods are more popular among larger firms and firms managed by CEOs with an MBA.

As table 2 shows, firms use DCF techniques mainly to help in deciding whether to expand in terms of new operations. The second and third most popular situations in which firms tend to use DCF techniques are mergers and acquisitions (M\&As) and expansion of existing operations. The results from the chi-square tests suggest that firm size and CEO education affect the popularity of DCF techniques. Consistent with figure 1, larger firms are more likely to use DCF methods in four of the seven situations presented in table 2, except expansion (new and existing operations) and M\&As where the chi-square test is not statistically significant. Approaches using DCF are also more popular in firms managed by CEOs with an MBA when such firms face decisions involving the expansion of existing operations, project replacement, and foreign operations.

Managers of Canadian firms generally appear to assess the riskiness of capital projects consistent with financial theory. First, the results from Panel A of figure 2 show that $84 \%$ of the respondents indicate that they differentiate between the riskiness of capital projects. This tendency is more pronounced in firms managed by CEOs with an MBA but does not seem to be influenced by firm size. Second, the results 


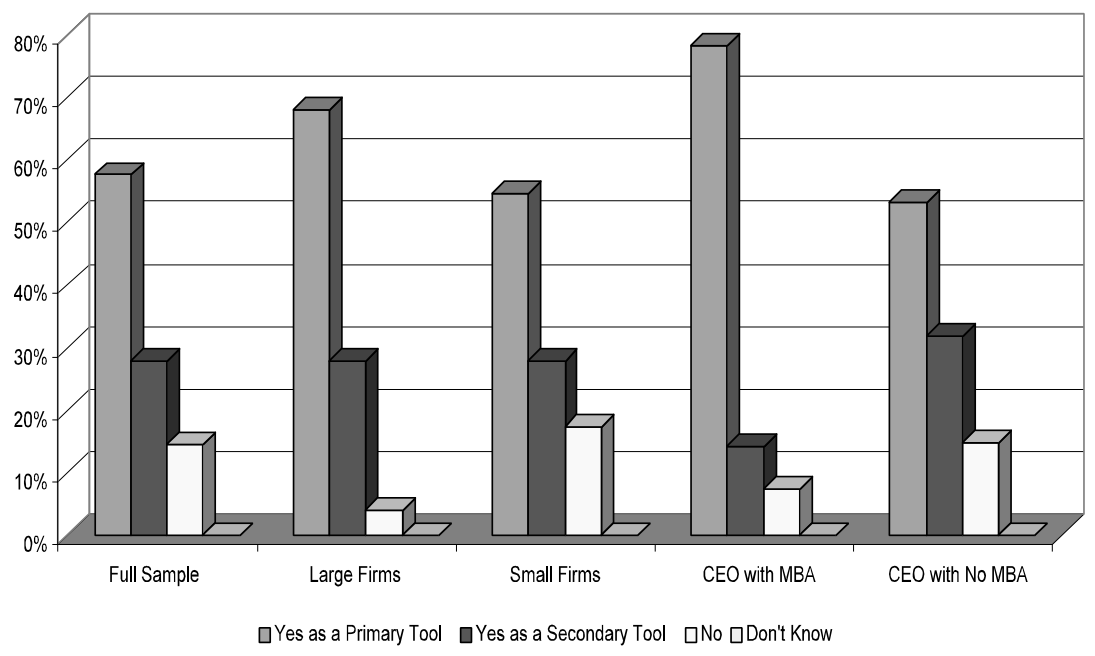

FIGURE 1.-Use of Discounted Cash Flow Techniques to Evaluate Investment Opportunities

Note: This figure provides the responses by managers of Canadian firms on whether their firms use DCF techniques to evaluate investment opportunities. The participants chose one answer among the following choices: (1) Yes as a primary tool, (2) Yes as a secondary tool, (3) No, and (4) Don't know. The figure partitions the sample by firm size (large and small) and by whether or not the firm's CEO holds an MBA.

from Panel B show that nearly $83 \%$ of respondents indicate that they measure project risk individually, while only $16 \%$ specify that they group projects into risk classes. This view is more pronounced for small firms (i.e., firms that have sales less than 100 million Canadian dollars) and firms managed by CEOs without an MBA. As Panel C shows, $44 \%$ of the responding managers indicate that they adjust the discount rate, $23 \%$ adjust the cash flow, and $26 \%$ adjust both the discount rate and the cash flow to account for the project riskiness. Firms managed by CEOs with an MBA are more likely to adjust the discount rate or cash flow than firms managed by CEOs without an MBA. The latter are more likely to adjust both.

In a 1991 survey of large Canadian firms, Jog and Srivastava (1995) report that the four most popular DCF techniques are IRR, NPV, PBP, and ARR. Their survey results suggest that IRR (in most cases) and PBP (in several cases) dominate the NPV method. The three other techniques (NPV, IRR, and PBP) always dominate the ARR. As table 3 shows, the 


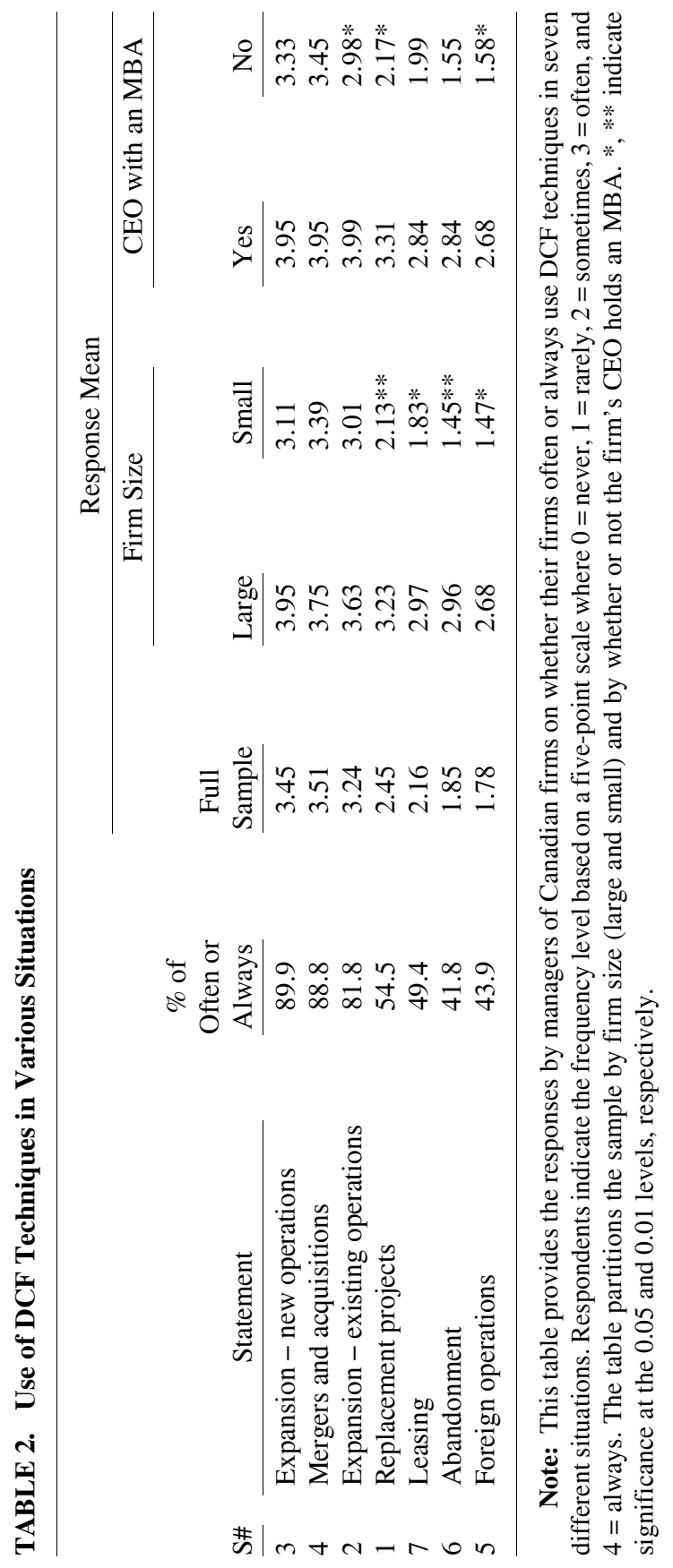


A. Survey responses on whether their firms differentiate between the riskiness of capital projects

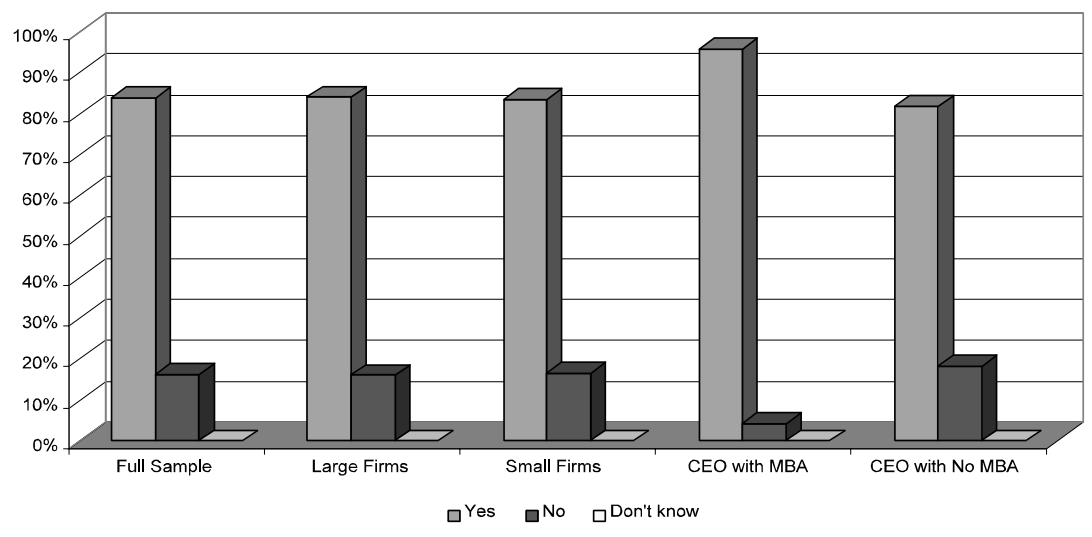

B. Survey responses on whether firms group projects into risk classes, measure project risk individually, or use another procedure

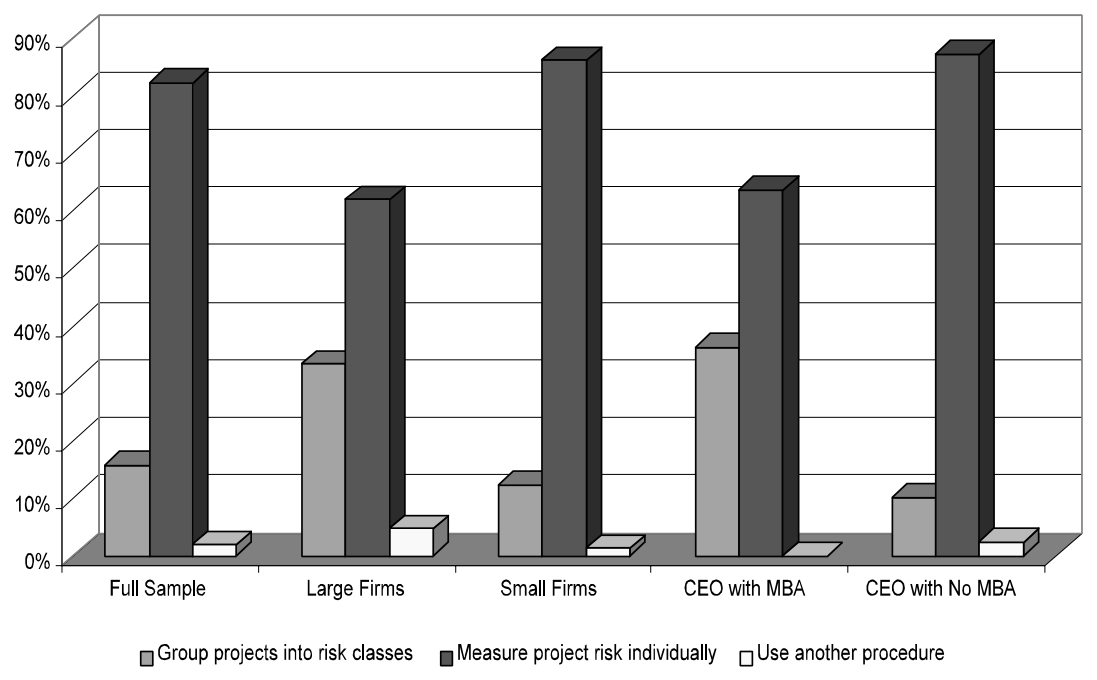


C. Percent of respondents using different approaches to adjust for project riskiness

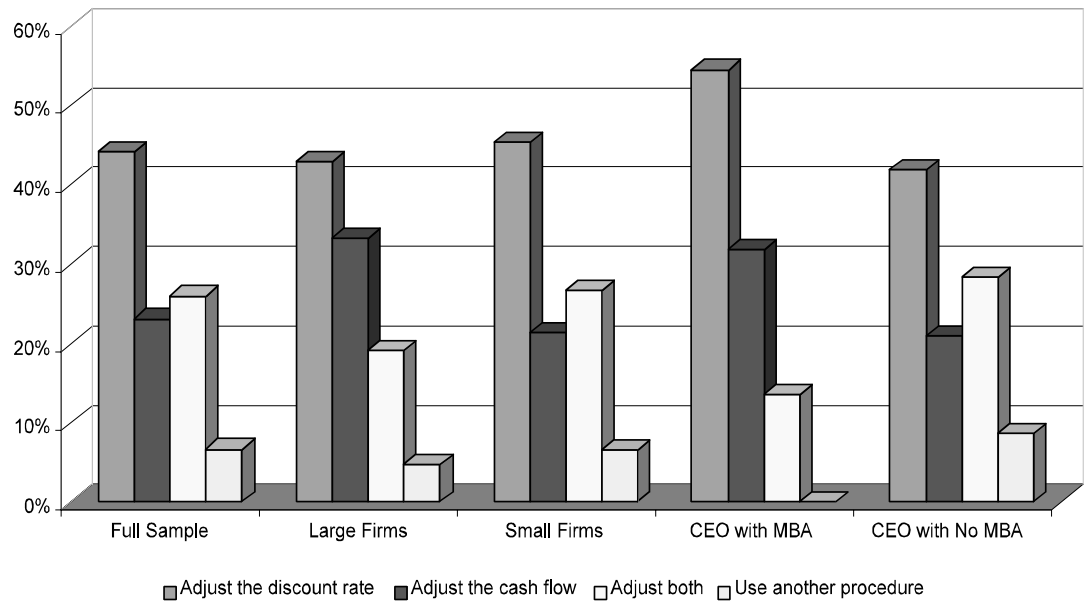

FIGURE 2.- Assessing Risk of Capital Budgeting Projects by Canadian Firms

Note: This figure provides the responses on how Canadian managers assess the riskiness of capital projects. Each figure partitions the sample by firm size (large and small) and by whether or not the firm's CEO holds an MBA.

updated survey, which includes both small and large firms, provides new insights on the capital budgeting techniques used by Canadian firms. Although, IRR, NPV, PBP, and ARR remain the most popular techniques, the evidence shows that consistent with finance theory NPV is the most popular method. In fact, nearly $75 \%$ of respondents indicate that they often or always use NPV, while about $68 \%$ and $67 \%$ often or always use IRR and PBP, respectively. Slightly less than $40 \%$ claim to use ARR often or always. While firm size or CEO education does not appear to influence the frequency of using NPV, IRR seems to be more popular in large firms. Hence, Jog and Srivastava's evidence reflects mainly the capital budgeting practices of large firms and should not be generalized to all Canadian firms.

The results also differ from recent U.S. and European evidence where IRR seems to be the most popular technique in the United States (Graham and Harvey, 2001) and PBP is the most frequently used capital budgeting technique in France, Germany, the Netherlands, and the 


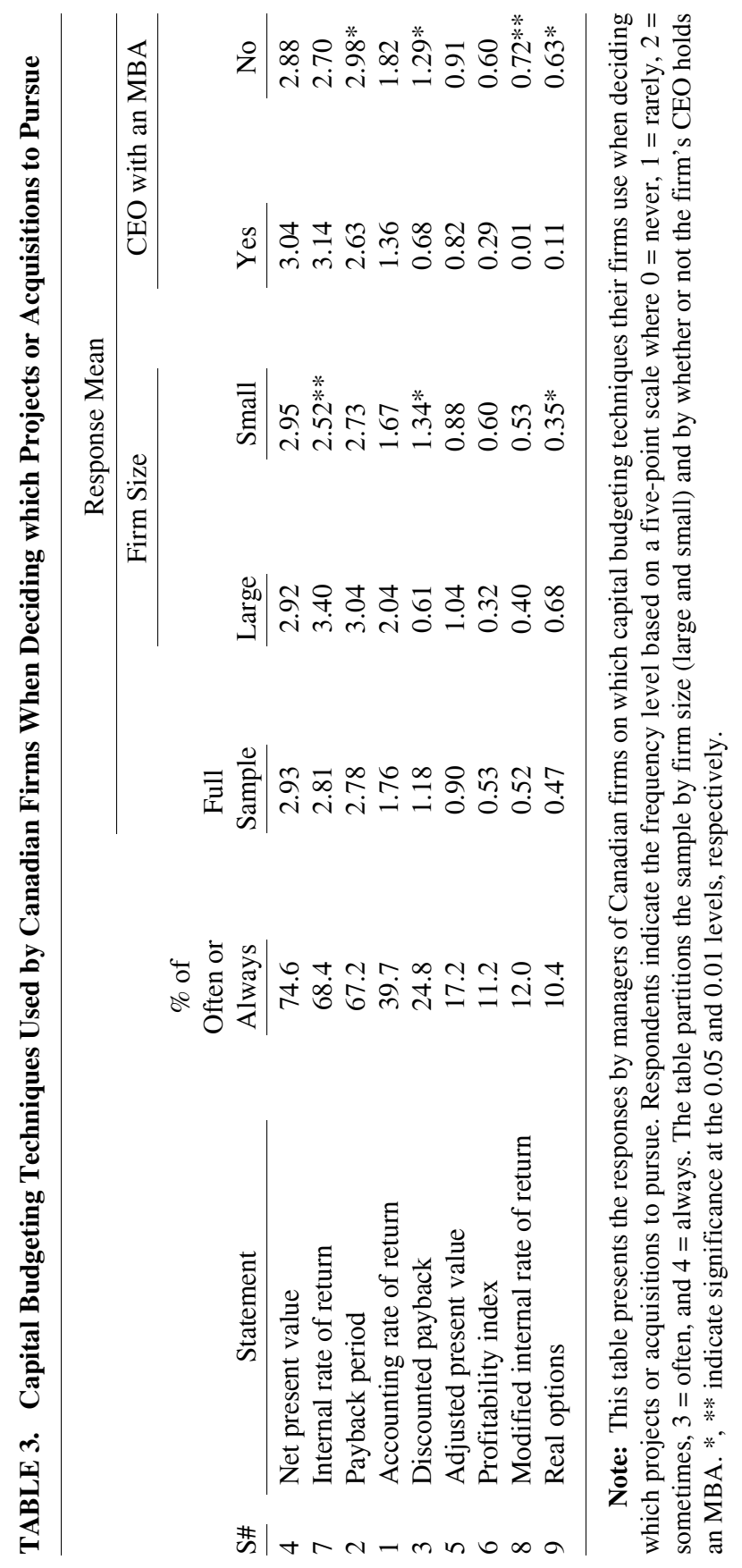




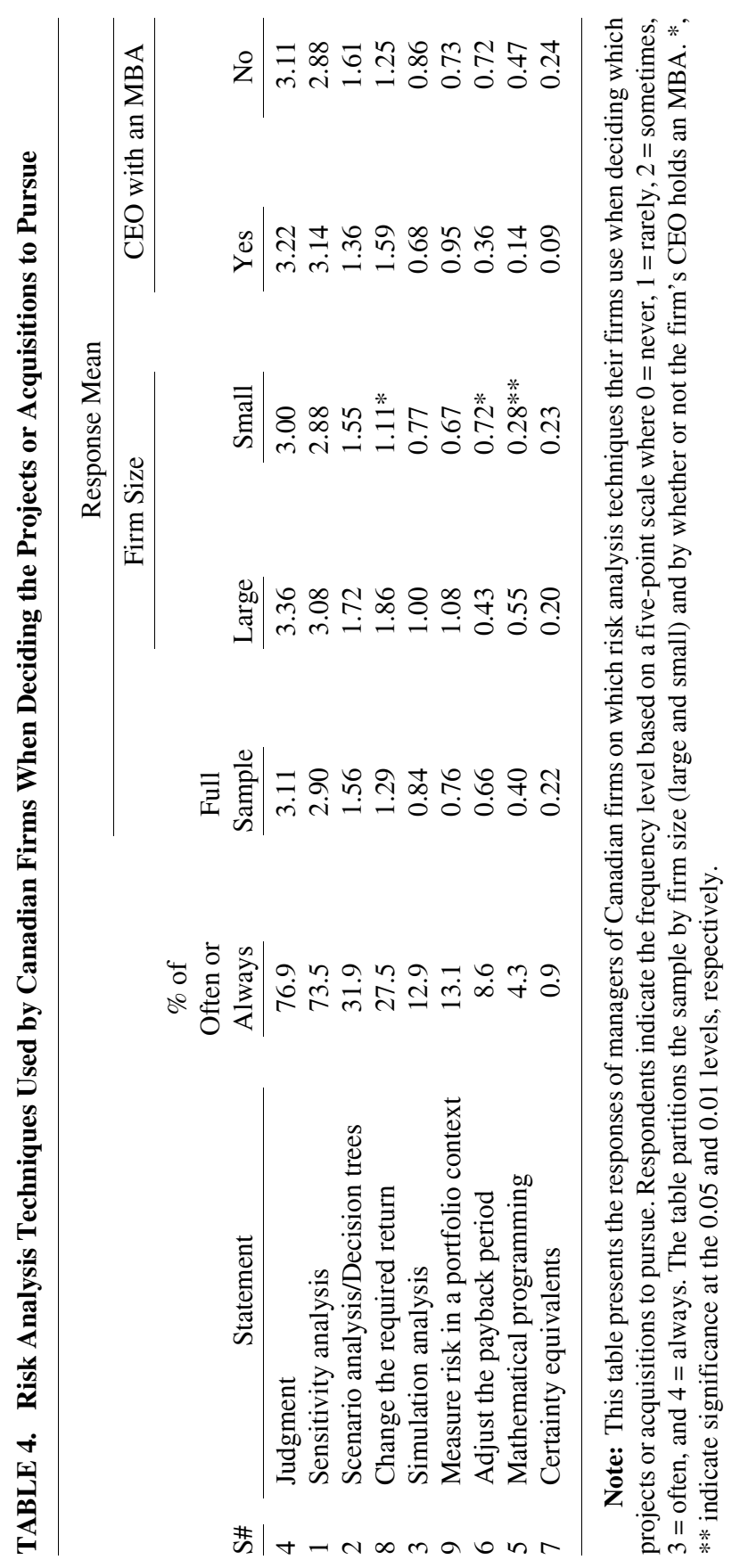


United Kingdom (Brounen, De Jong, and Koedijk (2004). Although the popularity of PBP has decreased over time, the method still enjoys wide usage especially among firms whose CEO does not hold an MBA. For example, consistent with Graham and Harvey, the results of the current study find that the use of payback is more popular in firms managed by CEOs who do not hold an MBA.

Of the nine capital budgeting techniques used by Canadian firms, the use of real options is the least popular technique. As table 3 shows, only $10.4 \%$ of the respondents report using real options often or always. Yet, larger firms and those managed by CEOs without an MBA appear to use real options more frequently. Although the latter finding appears counterintuitive, a potential explanation is that because MBA programs often focus more on traditional techniques with less coverage of real options, CEOs holding an MBA may be more likely to favor traditional approaches. Jagannathan and Meier (2002) link this behavior to the social desirability hypothesis developed in the psychology literature.

Table 4 presents survey responses regarding nine risk analysis techniques used by Canadian firms when deciding which projects or acquisitions to pursue. Contrary to finance theory, the most common is judgment, which $76.9 \%$ of the respondents report using often or always, followed closely by sensitivity analysis (73.5\%), and scenario analysis/decision-tree analysis (31.9\%). Not surprisingly, only a small percentage report using mathematical programming (4.3\%) and certainty equivalents $(0.9 \%)$ often or always.

\section{B. Cost of Capital, Capital Structure, and Capital Rationing}

Table 5 presents information on how frequently the responding firms use various discount rates when evaluating a new project. Consistent with finance theory, the majority of the companies (63.6\%) report using the company's overall discount rate (weighted average cost of capital or WACC) often or always. Using WACC appears more popular among large firms, which is consistent with the view that large firms tend to use more sophisticated approaches (Graham and Harvey, 2001). The second most popular alternative (43.5\%) relies on management's experience followed by the cost of specific funds planned for financing the project $(38.2 \%)$. Only $36.6 \%$ of respondents indicate using a risk-matched discount rate often or always, while $14.1 \%$ report employing a different discount rate for each cash flow that has a different risk characteristic. 


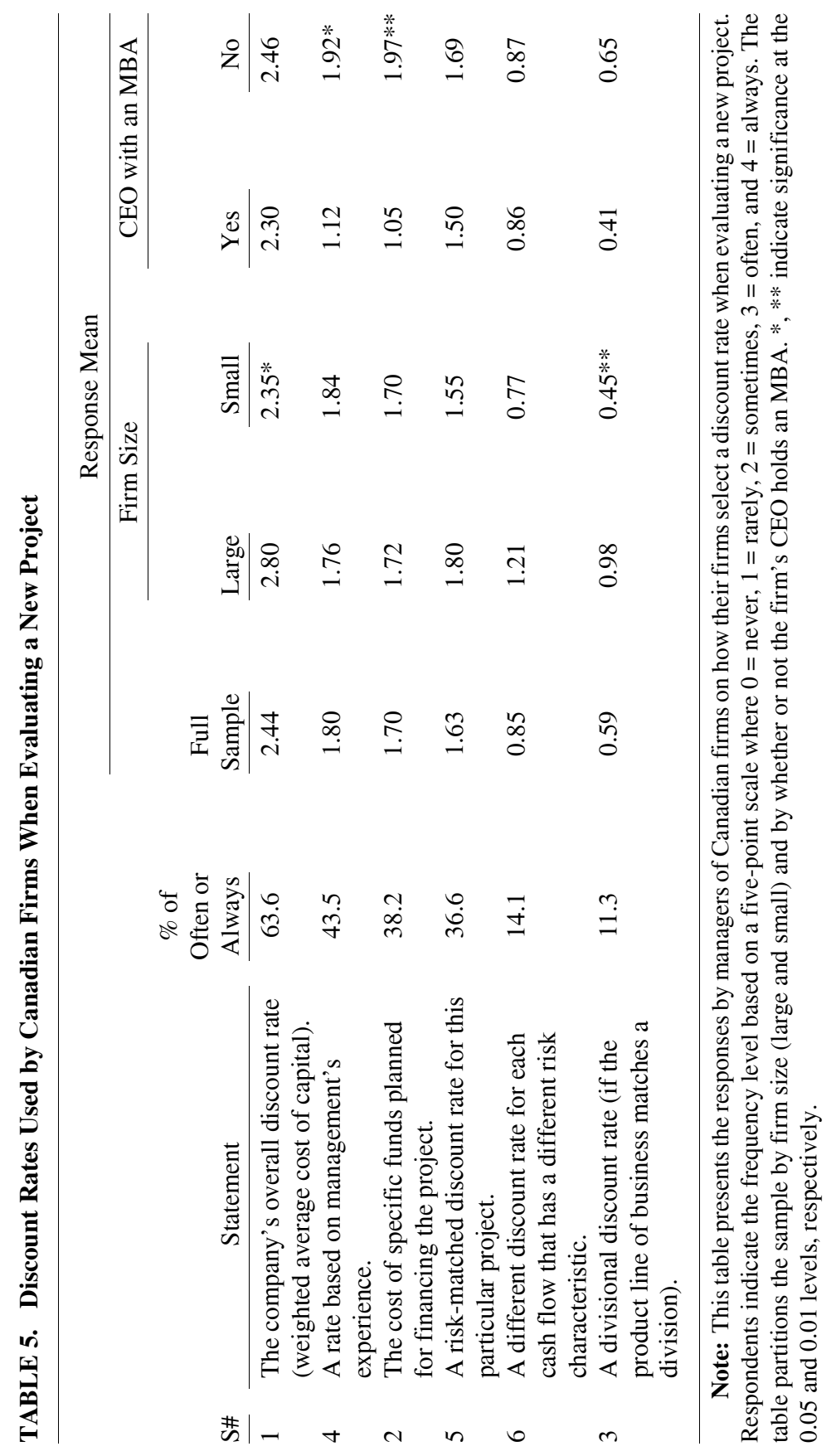




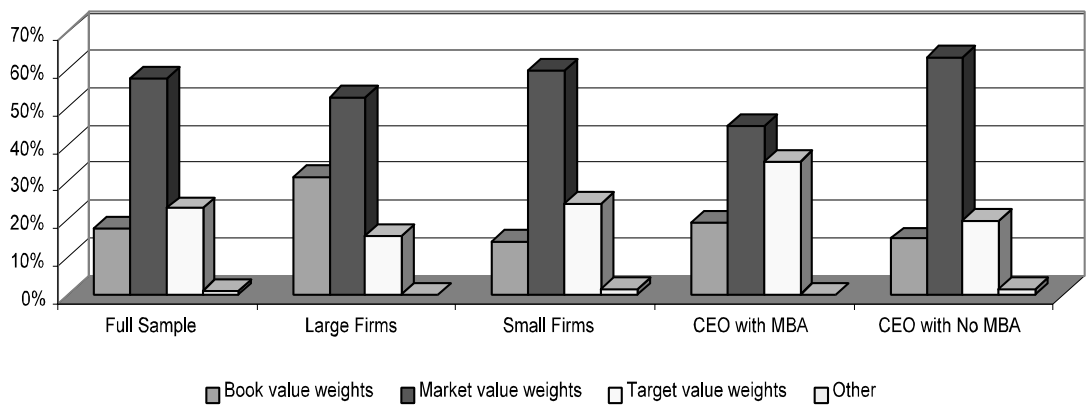

FIGURE 3.- Weighting Schemes Used by Canadian Firms to Compute Their WACC

Note: This figure provides the responses by Canadian firms on which weighting scheme their firms use to compute WACC. The figure partitions the sample by firm size (large and small) and by whether or not the firm's CEO holds an MBA.

Given that the majority of respondents report using their firm's WACC to evaluate new projects, respondents are asked to identify the weighting scheme used to calculate WACC. As figure 3 shows, in line with finance theory, the majority of the companies (57.7\%) use market value weights to get WACC. Surprisingly, however, the use of market value weights is more popular in small firms and firms managed by CEOs without an MBA. The second most popular weighting scheme for calculating WACC is target value weights $(23.1 \%)$ followed by book value weights $(18.0 \%)$.

As figure 4 shows, about $75 \%$ of the respondents indicate that their companies estimate the cost of equity capital, a result that seems consistent with theory. Large firms and those managed by CEOs holding an MBA are more likely to estimate the cost of equity capital. For those corporations that estimate their cost of equity capital, respondents are asked to indicate how they make their estimates from 10 choices. In contrast to finance theory, table 6 indicates that managers of Canadian firms tend to rely more on subjective judgment than on formal models when computing the cost of equity capital. In fact, $60.3 \%$ of respondents report using judgment often or always, compared to $52.3 \%$ using the cost of debt plus an equity premium. This evidence contrasts with their counterparts in the United States and Europe. For example, although the CAPM is the most popular technique in the United States (Graham and Harvey, 2001) and Europe (Brounen, De Jong, and Koedijk, 2004), only 


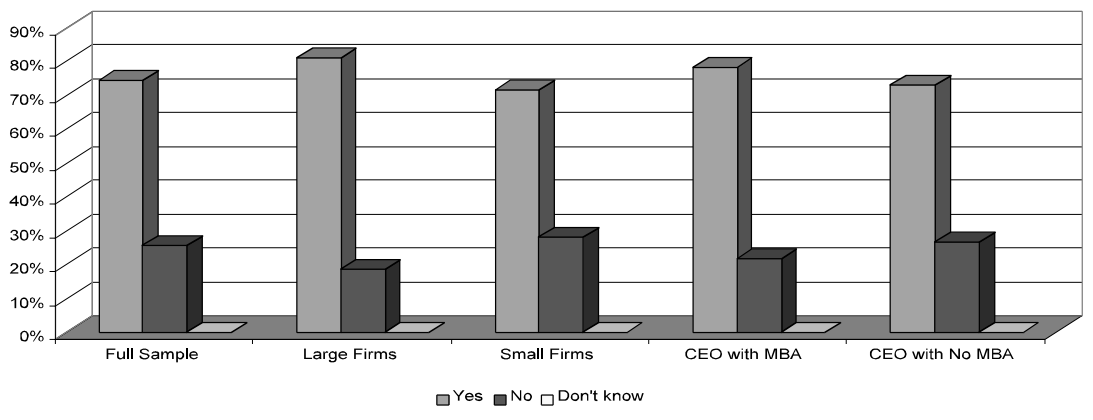

FIGURE 4.- Canadian Firms Reporting Whether They Estimate the Cost of Equity Capital

Note: This figure presents the responses by managers of Canadian firms on whether their firms estimate the cost of equity capital. The figure partitions the sample by firm size (large and small) and by whether or not the firm's CEO holds an MBA.

$36.8 \%$ of Canadian firms indicate using it often or always. The use of judgment is more pronounced in small firms while the CAPM is more popular in large firms. This evidence is consistent with the capital budgeting literature suggesting that small firms tend to use less sophisticated methods when setting their cost of capital (Brounen, De Jong, and Koedijk, 2004).

The use of subjective judgment by Canadian executives does not seem to be limited to computing the cost of equity capital and risk analysis but also to how they forecast project cash flows. In fact, table 7 shows that $94.0 \%$ of the respondents indicate a moderate or high reliance on management's subjective judgment in forecasting future cash flows, while $70.1 \%$ use quantitative methods, and $42.7 \%$ rely on consensus of experts' opinion. Neither firm size nor CEO education (holding an MBA) appears to affect these results.

The survey also examines the level of support for two competing theories of capital structure in a Canadian context, namely, static trade-off theory and pecking order theory. Trade-off theory suggests that a firm sets a target capital structure that reflects its trade off between the costs and benefits associated with debt. The pecking order theory of Myers and Majluf (1984) predicts that a firm does not have a target capital structure and finances new projects using retentions first followed by debt and then equity issues.

One way to directly test which capital structure theory is likely to 


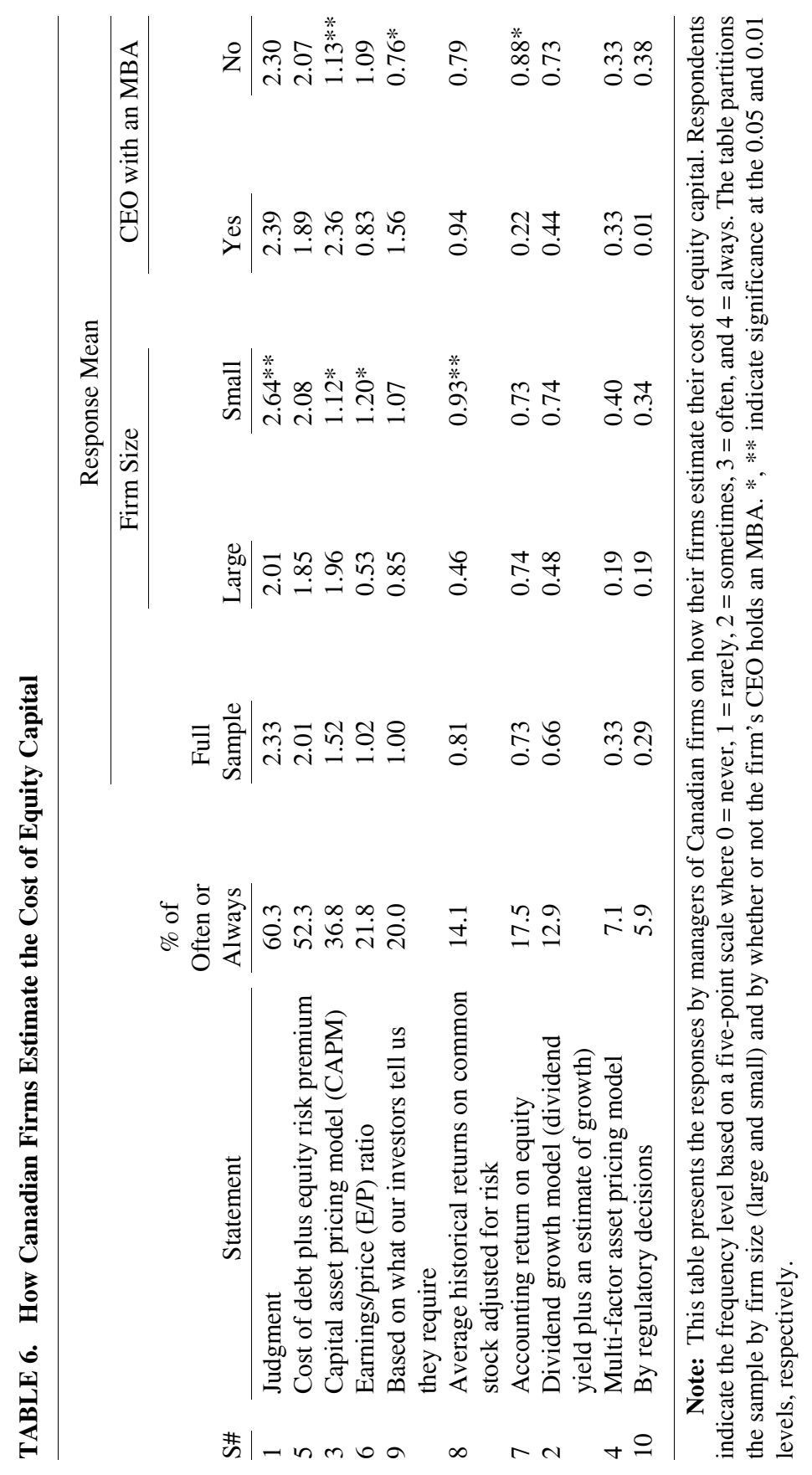




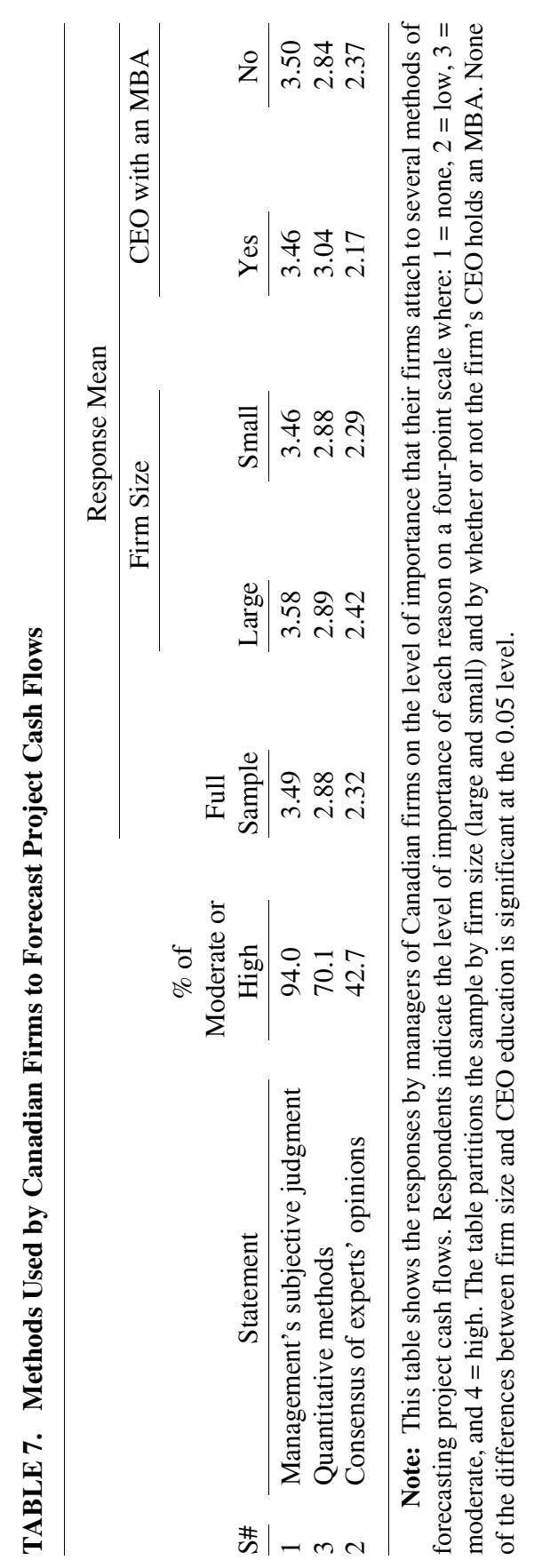


A. Survey responses to the question: "Does your firm have a target capital structure (debt-to-equity ratio)?"

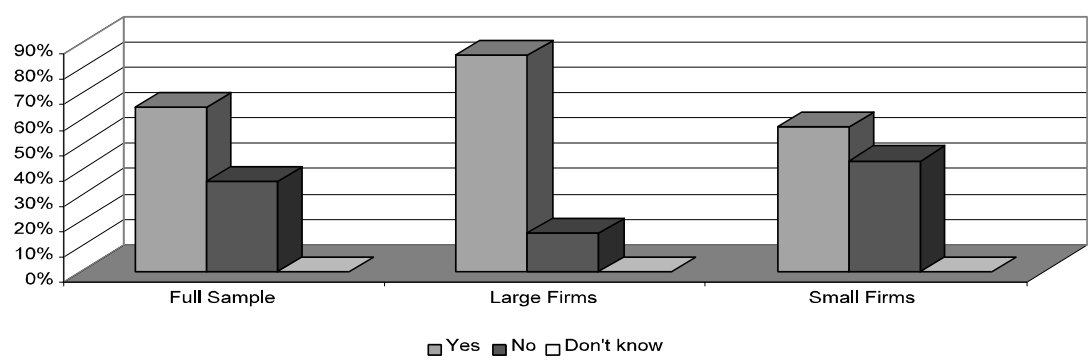

B. Survey responses to the question: "If 'Yes', what type of target debt ratio does your firm have?"

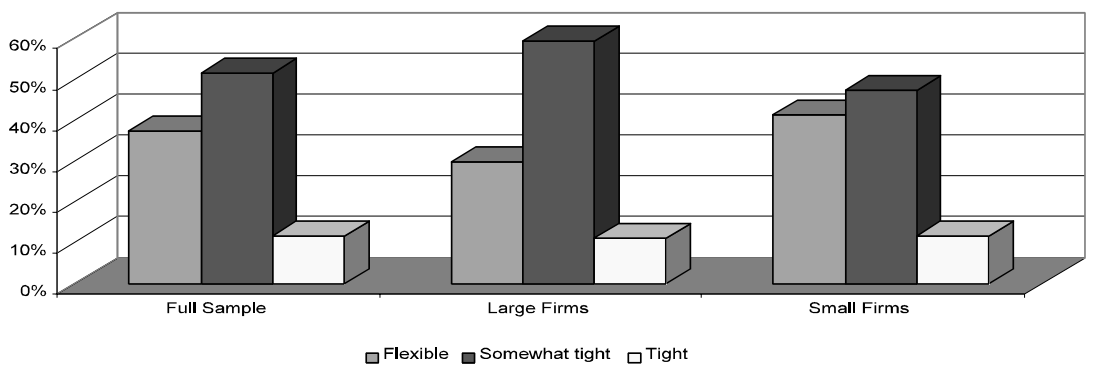

FIGURE 5.- Canadian Firms Reporting a Target Capital Structure

Note: This figure reports the responses by managers of Canadian firms on whether their firms have a target capital structure in Panel A and the degree of flexibility of their capital structure in Panel B. The figure partitions the sample by firm size (large and small).

hold for Canadian firms is to examine the percentage of firms having a target capital structure. According to the results presented in Panel A of figure 5 , the majority $(65 \%)$ of the respondents indicate that their firms have a target capital structure, which provides support for static trade-off theory. The percentage is smaller than that reported by Graham and Harvey (2001) and Brounen, De Jong, and Koedijk (2004) for the United States (83\%), the Netherlands (75\%), Germany (71\%). Still, the percentage is higher than the rate for the United Kingdom (60\%) and France $(43 \%)$.

Panel B of figure 5 presents the results on the degree of flexibility of a firm's target capital structure: flexible, somewhat tight, and tight. Unlike U.S. and European firms, the majority (53\%) of the Canadian 
firms have a somewhat tight target. A tight target capital structure is the least popular with only about $12 \%$ of respondents claiming this type of structure. Compared with smaller firms, a greater percentage of larger firms indicate a somewhat tight target debt ratio $(60 \%$ versus $47 \%)$ but a lower percentage have a flexible target ( $30 \%$ versus $41 \%$ ).

Respondents are also asked to indicate, to the nearest $10 \%$, the percentage of time that their firms face capital rationing (i.e., have more acceptable projects than funds available to invest). The survey results indicate that the mean percentage is $40 \%$. Compared with large firms, small firms are more likely to face capital rationing (43\% versus $34 \%$, respectively).

\section{Real Options}

As Baldwin (1987, p. 61) noted more than two decades ago "given the increase in variability in both product and financial markets worldwide, companies that recognize option values and build a degree of flexibility into their investments are likely to be at a significant advantage in the future, relative to companies that fail to take account of options in the design and evaluation of capital projects." Considering the current economic and financial turmoil, Baldwin's vision is more relevant today than ever. Unlike DCF techniques, real options enable firms to cope with high levels of uncertainty and allow for high levels of flexibility. Thus, real options potentially offer a more efficient way for managers to allocate their firm's capital and maximize shareholder value. Graham and Harvey (2001) find that $27 \%$ of their respondents report that their firms use real options. In fact, this approach ranks eighth among 12 capital budgeting techniques considered in their study.

The survey results indicate that real options are even less popular in Canada. As table 3 shows, using real options is the least popular approach among the nine capital budgeting techniques presented in the survey. When asked whether their company uses real options in making capital budgeting decisions $17 \%$ answer "yes," $79 \%$ respond "no", and $4 \%$ indicate "don't know." Thus, only 36 of the 214 respondents report that their firms use real options, while 169 indicate that their firms do not use real options. As expected, the real options approach is employed mainly by firms in industries characterized by large capital investments and considerable uncertainty and flexibility: mining (38.9\%), oil and gas (16.7\%), biotechnology (13.9\%), and pharmaceuticals $(11.1 \%)$.

To gain further insight about real options, the 36 respondents from 


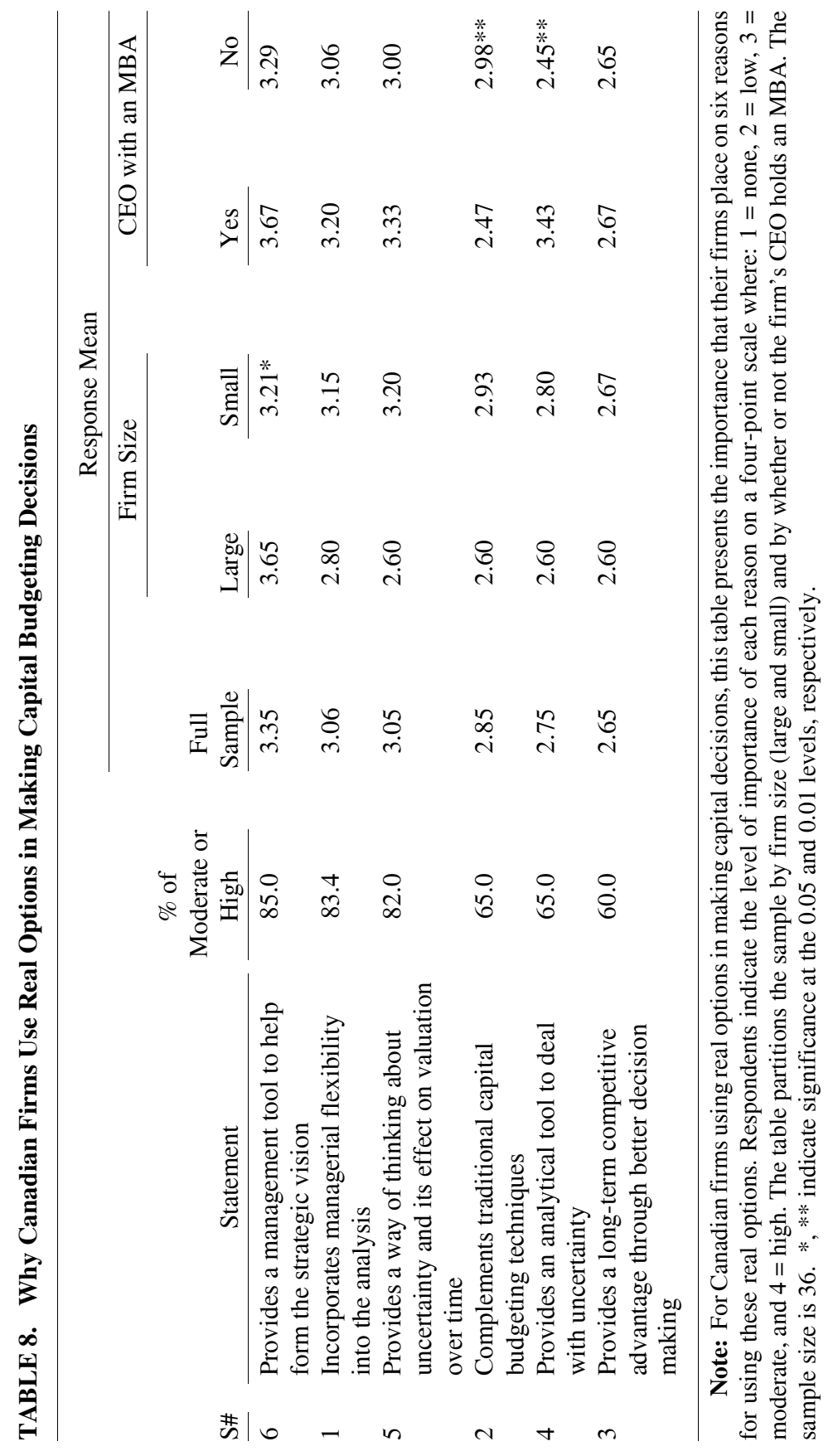




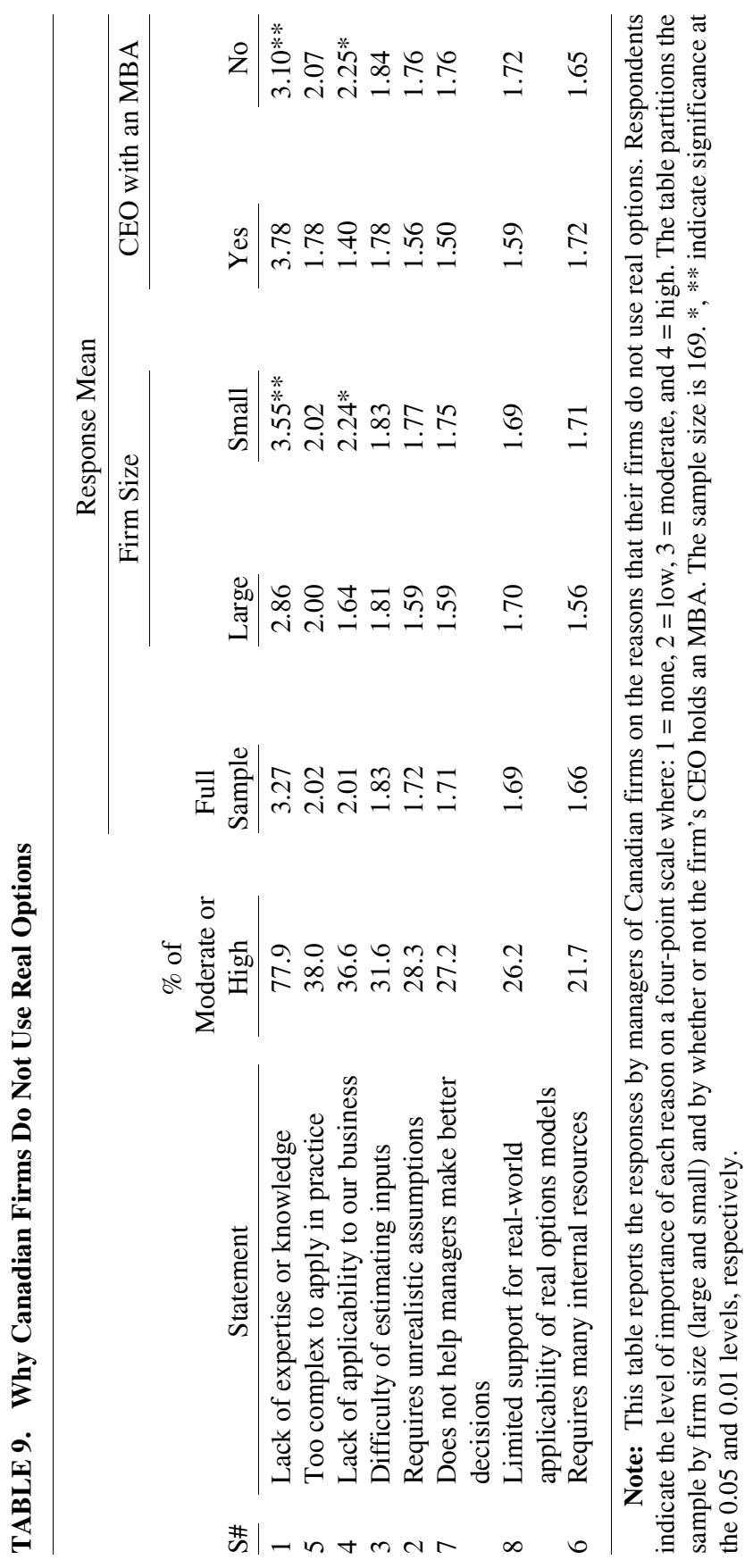


firms already employing real options are asked to indicate the importance of six reasons for using this approach in making capital budgeting decisions. As table 8 shows, at least $60 \%$ of these respondents view all six reasons for using real options as of moderate to high importance. The most important reason is that real options provide a management tool to help form the strategic vision. The next most highly ranked reasons for using real options are that they incorporate managerial flexibility into the analysis and provide a way of thinking about uncertainty and its effect on valuation over time.

Using an open-ended question, respondents are asked to state the most important reason for using real options. Based on 11 responses, the most common reasons are that real options tie closely to the true pace of business activities, challenge historical perspectives, fit a rational strategic planning model, and present an informal means to improve understanding and perspective.

As the survey indicates, the level of popularity of real options among Canadian firms appears relatively low, especially given the purported advantages associated with them compared to traditional techniques. Thus, managers of firms not using real options are asked to indicate the importance of eight reasons for not using them. As table 9 shows, the overwhelming reason for not using real options is the lack of expertise or knowledge. In fact, $77.9 \%$ of the respondents indicate that this reason is of moderate to high importance. The next most important reasons for not using real options concern their complexity and inapplicability.

Using an open-ended question, respondents are asked to indicate the major reason for their firms not using real options. Based on 29 responses, the evidence shows that these responses are consistent with the results reported in table 9. Representative responses to the open-ended question are: "What are real options?", "Don't know enough about it, but don't feel it's necessary", "We feel that it is not widely accepted yet in our industry", "Don't take time to understand them", "Never been exposed to it", "Never considered it", "Our decision making process works great, no desire to change", and "We are comfortable with our capital budgeting approach".

\section{Explaining the Difference between U.S. and Canadian Survey Results}

Several studies document that institutional differences influence corporate decision-making (Rajan and Zingales, 1995, 2003; La Porta et al., 1998; Aggarwal et al., 2009), which, in turn, may lead to country 
differences in corporate finance practices. Although the United States and Canada have well-developed equity markets, some important differences between these markets may explain why the survey results diverge between the two countries.

\section{A. Difference in Corporate Governance and Ownership Structure}

According to Brounen, De Jong, and Koedijk (2004), firms that attempt to maximize shareholder value are likely to use advanced and theoretically correct capital budgeting techniques. This finding is consist with La Porta et al. (1998) and others who stress that corporate governance and ownership structure determine whether insiders' (managers and controlling shareholders) main objective is to maximize minority shareholders wealth or to extract private benefit of control.

The United States and Canada differ in several features of ownership structure and corporate governance. Morck, Strangeland, and Yeung (2001, p. 327) assert that these economies "have broadly similar factor endowments, and employ virtually identical technology and human capital in similar institutional frameworks" except for their ownership structure. Ownership is highly concentrated in Canadian public firms but widely diffused in U.S. public firms. In Canada, a small group of large blockholders, or affiliated groups of investors, dominate the ownership scene. Wealthy families maintain some influence over public officials through different control mechanisms such as pyramidal holdings, cross holdings, and multiple class shares. In fact, Morck, Strangeland, and Yeung (2001) find that 254 of the 500 largest Canadian companies represent privately-held firms. The remaining 246 are public firms of which only 53 have broad ownership. Attig and Gadhoum (2003) extend Morck, Strangeland, and Yeung's (2001) analysis and find that more than $80 \%$ of all Canadian public firms have controlling shareholders with $40 \%$ controlled by wealthy family groups. Attig and Gadhoum also report that $33 \%$ of public firms are controlled through pyramidal structures while $16 \%$ are controlled through shares with superior voting rights. More recently, in a sample of 263 Canadian firms, Klein, Shapiro, and Young (2005) find 123 widely-held firms, and 140 closely-held firms, of which 84 are family-owned.

Recent allegations of corporate wrongdoings in Canada such as Hollinger Inc. and Royal Group Technologies Inc. typify the use of control pyramids and multiple-class shares in expropriating minority shareholders. These governance failures allegedly involved related-party transactions and large fund transfers in the form of management 
agreements and improper "non-compete" fees from affiliated firms to their ultimate owners. In fact, many Canadian firms also use a dual-class share structure (Amoako-Adu and Smith, 1995; Attig, 2005; King and Segal, 2009). For instance, King and Segal document that about $20 \%$ of Canadian public firms have dual-class shares. Clearly, the corporate ownership and control structure in Canada differs substantially from the freestanding, widely-held firm prototype customary in the United States and the United Kingdom.

Furthermore, while the U.S. corporate governance regime is mandatory, the Canadian regime is largely voluntary (Anand, 2005). Anand, Milne, and Purda (2006), who examine the governance practices of Canadian firms listed on the Toronto Stock Exchange from 1999 to 2003, find that the presence of an executive blockholder or a majority shareholder is negatively associated with voluntary adoption of the corporate governance regime.

Moreover, various empirical studies suggest that Canadian corporate governance is weaker than that in the United States (Jabbour, Jalilvand, and Switzer, 2000; McNally and Smith, 2003). Bris (2005), for example, argues that Canada ranks behind the United States with respect to law enforcement, mandatory disclosure, illegal insider trading, and other aspects of regulatory regime. King and Segal (2003) examine why equity of Canadian-listed firms trades at a discount to equity of Canadian firms cross listed on both a Canadian and a U.S. stock exchange. The authors show that the valuation discount is due to the weaker corporate governance in Canada relative to the United States.

The higher concentration of ownership in Canadian firms coupled with a relatively weak Canadian corporate governance system may exacerbate managerial opportunism, which in turn could result in not using corporate finance practices that maximize minority shareholders' value. Consistent with this view Athanassakos (2007) shows that the lack of value-based management in Canada helps to explain the underperformance of the Canadian stock market during the 1990s relative to the United States.

\section{B. Firm Size}

The results suggest that Canadian managers rely more on subjective judgment than other methods when adjusting their discount rate, analyzing risk, forecasting project cash flow, and estimating the cost of equity capital. This finding differs markedly from the widespread use of the CAPM by U.S. firms. Canadian managers are also less likely to 
use real options. These differences could be due to the smaller size, on average, of Canadian firms relative to U.S. firms (Leung, Meh, and Terajima, 2008). In fact, Graham and Harvey (2001), among others, document fundamental differences between large and small firms when analyzing corporate finance practices. Specifically, they report that smaller firms tend to use less sophisticated methods, which is consistent with Canadian firms relying more on subjective judgment rather than using more analytical or sophisticated approaches.

\section{Summary and Conclusions}

This study uses a survey to investigate financial practices of Canadian firms involving capital budgeting, cost of capital estimation, capital structure, and real options. What are the major findings from this study? Consistent with finance theory, the findings on capital budgeting practices show a strong preference for NPV followed by IRR and PBP. In contrast to theory, Canadian managers, however, rely mainly on subjective judgment when dealing with risk analysis and to a slightly lesser extent on sensitivity analysis.

The survey also examines the approach that Canadian firms use to incorporate differential project risk into their analysis. Although responding firms tend to differentiate between the riskiness of capital projects as recommended by finance theory, they rely mainly on subjective risk assessments in adjusting the discount rate. The majority of respondents use a WACC based on market value weights as an appropriate discount rate when evaluating an average risk project. The use of subjective judgment by Canadian managers also applies both to forecasting project cash flows and to estimating the cost of equity capital. This latter finding contrasts with the widespread use of the CAPM by U.S. and European firms. In examining capital structure choice, the evidence finds support for the trade-off theory relative to pecking-order theory.

Contrary to the optimistic predictions from the academic and professional community, the use of real options appears disproportionate to its potential as a powerful capital budgeting and management tool. The evidence shows that the major reason for firms not using real options is the lack of expertise and knowledge rather than the features and design of real options.

Finally, the evidence indicates that both firm size and CEO education influence some corporate finance practices. For example, 
large firms and firms managed by CEOs with an MBA tend to use more sophisticated techniques when evaluating new projects and when estimating the cost of equity capital. The study also documents that large firms are more likely to use real options but that real options are less popular in firms managed by CEOs with an MBA.

What are the implications of the findings for practitioners and academics? Taken together, the findings show that despite improvements in finance practices in Canada over time, more effort is needed to encourage Canadian firms, particularly small ones, to use more objective approaches and to take greater advantage of real options analysis. Using sub-optimal approaches is likely to negatively influence firm value and hence stock price performance as discussed by Athanassakos (2007).

The study also shows that "one size does not fit all" involving corporate finance practices. Important institutional and other differences exist between countries and in such areas as corporate governance, ownership structure, and firm size. Because such differences could influence managerial decisions about which finance practices they use, researchers need to consider them.

Another implication of the study involves the use of real options. The survey evidence provides support for Triantis (2005) who calls for academic research that integrates practitioners' concerns about applying real options to real world cases. Triantis (p. 16) notes, "Academics must listen carefully to the critiques of practitioners and allow them to influence the kinds of problems that are addressed in academic research. To the extent that we can be responsive to the concerns of practitioners, and improve the normative models we offer them, real options will have the type of profound impact that we have long been expecting, but which has not yet been realized." Because the low popularity of real options among Canadian managers is mainly due to a lack of expertise and knowledge, business schools have the opportunity to place greater emphasis on this powerful tool in their MBA and other programs.

Accepted by: Prof. P. Theodossiou, Editor-in-Chief, May 2011

\section{References}

Aggarwal, R.; Erel, I.; Stulz, R.; and Williamson, R. 2009. Differences in governance practices between U.S. and Foreign firms: Measurement, causes, and consequences. Review of Financial Studies 22(8): 3131-3169. 
Amoako-Adu, B., and Smith, B. 1995. Relative prices of dual-class shares. Journal of Financial and Quantitative Analysis 30(2): 223-239.

Anand, A. 2005. An analysis of enabling vs. mandatory corporate governance post Sarbanes-Oxley. Delaware Journal of Corporate Law 31(1): 229-252.

Anand, A.; Milne, F.; and Purda, L. 2006. Voluntary adoption of corporate governance mechanisms. American Law and Economics Association Meetings.

Athanassakos, G. 2007. Value-based management, EVA and stock price performance in Canada. Journal of Management Decision 45(9): $1397-1411$.

Attig, N. 2005. Balance of power. Canadian Investment Review 18(3): 6-13.

Attig, N., and Gadhoum, Y. 2003. The governance of Canadian traded firms: An analysis of the ultimate ownership structure. Working paper. Montreal: University of Quebec.

Baker, H. K.; Chang, B.; Dutta, S.; and Saadi, S. 2009. Why firms do not pay dividends: The Canadian experience. $5^{\text {th }}$ International Finance Conference (ICF) Meetings. Hammamet, March 12-14.

Baker, H. K.; Singleton, J. C.; and Veit, T. E. 2011. Survey Research in Corporate Finance - Bridging the Gap between Theory and Practice. Oxford and New York: Oxford University Press.

Baldwin, C. 1987. Competing for capital in a global environment. Midland Corporate Finance Journal 5(1): 43-64.

Block, S. 2007. Are 'real options' actually used in the real world? The Engineering Economist 52(3): 255-267.

Brealey, R.; Myers, S.; and Allen, F. 2007. Principles of Corporate Finance. New York: McGraw-Hill/lrwin.

Brennan, M. J., and Schwartz, E. S. 1985. Evaluating natural resource investments. Journal of Business 58(2): 135-157.

Bris, A. 2005. Do insider trading laws work? European Financial Management 11(3): 267-312.

Brounen, D.; De Jong, A.; and Koedijk, K. 2004. Corporate finance in Europe: Confronting theory with practice. Financial Management 34(4): 71-101.

Chance, D. M., and Peterson, P. P. 2002. Real Options and Investment Valuation. Charlottesville, VA: Research Foundation of AIMR.

Chew, D. 1997. Studies in International Corporate Finance and Governance Systems: A Comparison of the U.S., Japan, and Europe. Oxford and New York: Oxford University Press.

Chu, H., and Partington, G. 2001. Dangers in data adjustment: The case of rights issues and returns. Accounting and Finance 41(2): 143-168.

Gitman, L., and Mercurio, V. 1982. Cost of capital techniques used by major U.S. firms: Survey and analysis of Fortune's 1000. Financial Management 11(4): 21-29.

Gitman, L., and Vandenberg, P. 2000. Cost of capital techniques used by major U.S. firms: 1997 vs. 1980. Financial Practice and Education 10(2): 53-68. 
Graham, J., and Harvey, C. 2001. The theory and practice of corporate finance: Evidence from the field. Journal of Financial Economics 60(2-3): 187-243.

Ingersoll, J. E., and Ross, S. A. 1992. Waiting to invest: Investment and uncertainty. Journal of Business 65(1): 1-30.

Istvan, D. F. 1961. The economic evaluation of capital expenditures. Journal of Business 34(1): 45-51.

Jabbour, A. R.; Jalilvand, A.; and Switzer, J. A. 2000. Pre-bid price run-ups and insider trading activity: Evidence from Canadian acquisitions. International Review of Financial Analysis 9(1): 21-43.

Jagannathan, R., and Meier, I. 2002. Do we need CAPM for capital budgeting? Financial Management 31(4): 5-27.

Jog, V., and Srivastava, A. 1995. Capital budgeting practices in corporate Canada. Financial Practice and Education 5(2): 37-43.

King, M. R., and Segal, D. 2003. Corporate governance, international cross listing and home bias. Canadian Investment Review 16(4): 8-19.

King, M. R., and Segal, D. 2009. The long-term effects of cross-listing, investor recognition, and ownership structure on valuation. Review of Financial Studies 22(6): 2393-2421.

Klein, P.; Shapiro, D.; and Young, J. 2005. Corporate governance, family ownership and firm value: The Canadian evidence. Corporate Governance: An International Review 13(6): 769-784.

La Porta, R.; Lopez-de-Silanes, F. ; Shleifer, A. ; and Vishny, R. W. 1998. Law and finance. Journal of Political Economy 106(6): 1113-1155.

Lasfer, M., and Alzahrani, M. 2009. The impact of taxation on dividends: A cross-country analysis. Working paper. Cass Business School.

Leung, D.; Meh, C.; and Terajima, Y. 2008. Productivity in Canada: Does firm size matter? Bank of Canada Review (Autumn), 7-16.

McNally, W. J., and Smith, B. F. 2003. Do insiders play by the rules? Canadian Public Policy 29(2): 125-144.

Morck, R.; Stangeland, D. A.; and Yeung, B. 2001. Inherited wealth, corporate control, and economic growth: The Canadian disease. In R. K. Morck (ed.). Concentrated Corporate Ownership, 319-369. Chicago: University of Chicago Press.

Myers, S., and Majluf, N. 1984. Corporate financing and investment decisions when firms have information that investors do not have. Journal of Financial Economics 13(2): 187-221.

Paddock, J. D.; Siegel, D.; and Smith, J. 1988. Option valuation of claims on real assets: The case of offshore petroleum leases. Quarterly Journal of Economics 103(3): 479-508.

Pindyck, R. 1991. Irreversible investment, uncertainty and investment. Journal of Economic Literature 29(3):1110-1152. 
Rajan, R. G., and Zingales, L. 1995. What do we know about capital structure? Some evidence from international data. Journal of Finance 50(5): 1421-1460.

Rajan, R. G., and Zingales, L. 2003. The great reversals: The politics of financial development in the twentieth Century. Journal of Financial Economics 69(1): 5-50.

Trahan, E. A., and Gitman, L. J. 1995. Bridging the theory-practice gap: A survey of chief financial officers. Quarterly Review of Economics and Finance 35(1): 73-87.

Triantis, A. J. 2005. Realizing the potential of real options: Does theory meet practice? Journal of Applied Corporate Finance 17(2): 8-16.

Triantis, A. J., and Borison, A. 2001. Real options: State of the practice. Journal of Applied Corporate Finance 14(2): 8-24.

Trigeorgis, L. 1993. The nature of option interactions and the valuation of investments with multiple real options. Journal of Financial and Quantitative Analysis 28(1): 1-20.

Wallace, R. S. O., and Mellor, C. J. 1988. Non-response bias in mail accounting surveys: A pedagogical note. British Accounting Review 20(2): 131-139. 